\title{
Lessons from stakeholder dialogues on marine aquaculture in offshore wind farms: Perceived potentials, constraints and research gaps
}

\author{
Lara Wever $^{\mathrm{a}, *}$, Gesche Krause ${ }^{\mathrm{b}, \mathrm{c}}$, Bela H. Buck ${ }^{\mathrm{b}, \mathrm{d}}$ \\ a Institute for Marine Resources $\mathrm{GmbH}$, Bussestrasse 27-29, 27570 Bremerhaven, Germany \\ ${ }^{\mathrm{b}}$ Alfred Wegener Institute Helmholtz-Center for Polar and Marine Research, Am Handelshafen 12, 27570 Bremerhaven, Germany \\ ' SeaKult, Sandfahrel 12, 27572 Bremerhaven, Germany \\ d University of Applied Sciences Bremerhaven, An der Karlstadt 8, 27568 Bremerhaven, Germany
}

\section{A R T I C L E I N F O}

\section{Article history:}

Received 30 April 2014

Received in revised form

22 August 2014

Accepted 22 August 2014

\section{Keywords:}

Stakeholder analysis

Marine aquaculture

Multi-use

Offshore wind farms

Stakeholder dialogues

Transdisciplinary research

\begin{abstract}
A B S T R A C T
Drawing on a case study in Germany, this contribution explores the practical application of offshore aquaculture within offshore wind farms in view of the different stakeholders involved. Using a transdisciplinary research approach, an understanding of the rationalities and interests among the different involved stakeholder groups was explored. Offshore wind energy is high on the political agenda in Germany. The vast spatial requirements however inherit potential user conflicts with competing, and under current legislation excluded users such as fishermen. Solutions for combining sustainable uses of the same ocean space have thus seen increasing interest within the research community in Germany and in Europe over the past years. This paper was inspired by and presents the outcomes of a stakeholder analysis and in particular a stakeholder workshop. Central focus was placed on academics and private as well as public stakeholders engaged in current research efforts of combining offshore wind farms and aquaculture in the German North Sea. The paper identifies the overall acceptance of such a multi-use scenario in society, opportunities and constraints as perceived by the stakeholders, and key research gaps. The results confirm the assumption that there is a clear need, and also willingness on behalf of the policy makers and the research community, to find sustainable, resource- and space-efficient solutions for combined ocean use.
\end{abstract}

(c) 2014 Elsevier Ltd. All rights reserved.

\section{Introduction}

The idea to combine offshore wind farm turbines as fixation point for aquaculture or to co-use an offshore wind farm site by installing aquaculture farms in between several wind turbines has seen considerable attention over the course of the last years (see for instance in the case of Germany: [1-3], The Netherlands: [4], Belgium: [5], UK: [6], France: [7]) (see Fig. 1).

While a significant body of research exists covering individual uses for offshore platforms, the interaction between these multiple uses has not been covered to a full extent on a European scale. This has changed with the recent call of the European Commission "Ocean of Tomorrow", issued under the FP7 in 2011, which reflects the current state of "European Strategy for Marine and Maritime Research" (see Fig. 2).

In a first step, the aim of the call is to establish offshore platforms that can combine various functions, such as aquaculture, wind and

\footnotetext{
* Corresponding author. Present address: Forschungszentrum Jülich GmbH, Wilhelm-Johnen-Strasse, 52428 Jülich, Germany. Tel.: + 492118755361524.

E-mail address: lara.wever@gmx.de (L. Wever).
}

solar energy, and transport services within the same infrastructure. It is believed that this could offer significant benefits in terms of economics, optimizing spatial planning and minimizing the impact on the environment.

In Germany, no commercial offshore aquaculture farm exists yet. To date, all attempts to move bivalve aquaculture off the coast to a more hostile environment within wind farm areas are on a pilot scale. Various projects including scientific studies on the biology, techniques and system design, economic potential, Integrated Coastal Zone Management (ICZM), and the regulatory framework as well as potential synergies with offshore wind turbines have been investigated. A number of projects are underway to test the feasibility of offshore farming in the Exclusive Economic Zone (EEZ) of the German Bight, such as the ongoing project Offshore-Site-Selection (OSS). Here, wind farm planners as well as representatives of fisheries, economics and science are together suggesting future sites with best conditions for the cultivation of various aquaculture species.

In its wake, the multi-disciplinary project "Open Ocean MultiUse" (OOMU) funded by the German Federal Ministry for the Environment, Nature Conservation and Nuclear Safety was initiated $[23,24]$. This project was a follow-up project of a series of multi-use 


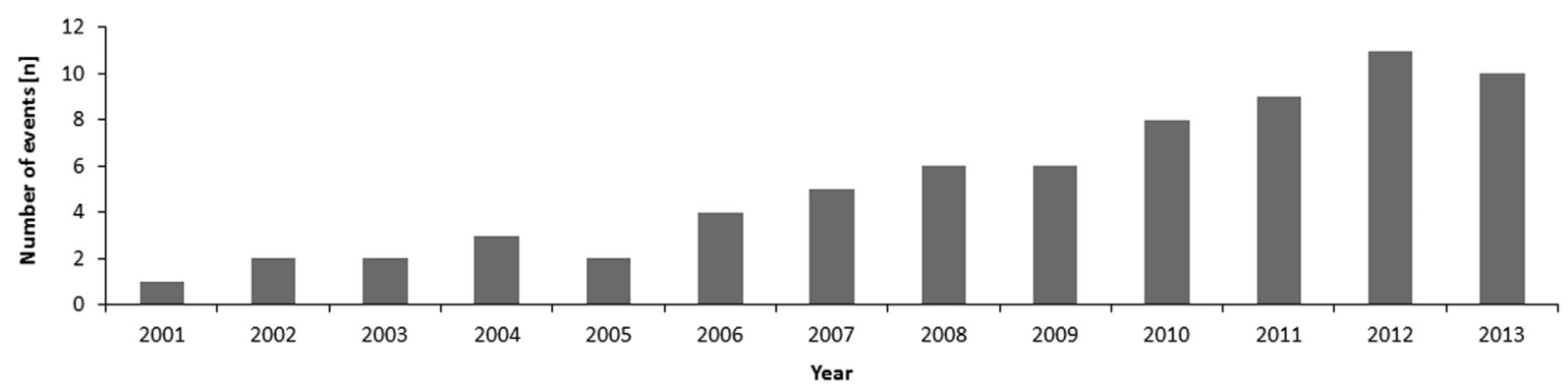

Fig. 1. Graph shows a timescale with the number of events worldwide in which the combination of aquaculture within offshore wind farms was discussed [8-22].

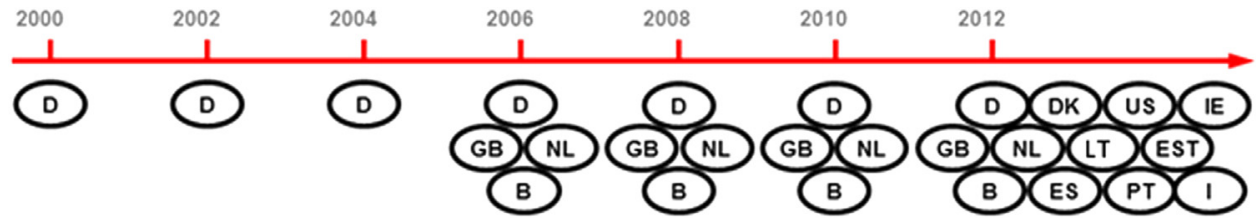

Fig. 2. Countries involved in aquaculture $\Leftrightarrow$ wind farm combinations on a time line

projects combining aquaculture with offshore wind farms (see results e.g. in [2,3]). Central focus of the OOMU-project was to gain more insight into the biological, socio-economic and technical aspects as well as to develop practical solutions for potential problems encountered by integrating aquaculture installations into offshore wind energy facilities. One of the key questions of the socio-economics sub-project was to identify the acceptance of such a multi-use scenario in society at large by addressing the various stakeholder groups simultaneously. By this it was hoped to detect hidden agendas, conflicts and allies, all of which directly and indirectly affect the reasoning of these groups in regard to multiuse of offshore areas. Thus, the approach used here is a transdisciplinary one, meaning that next to the interdisciplinary discourse among different strands of scientific disciplines, a range of different stakeholders from the private-public nexus is involved in the research effort [25].

The main motivation to broaden the scientific community and to include various forms of knowledge is based on the insight that successful and applicable solutions of many environmental and social problems, such as sustainable food production and renewable energy production, can only be found if actors and natural processes at the local, regional, national, and global level are conflated [26]. Much of this is related to social learning. Thus, knowing is an act of participation in complex "social learning systems" [27]. Beginning in the 1970s, the notion of social learning gained attention in many disciplines such as political science, in which the role played by advocacy coalitions in processes of societal change and learning was underlined [28]. Today, social learning can be regarded as an essential element of policy development and implementation. The sustainability-science approach is especially dependent on the inclusion of participatory elements in knowledge production [26]. By including the knowledge and interests of the diverse range set of stakeholders in the very beginning, this issue can be understood as learning of whole societies as a common endeavour [29,30]. Indeed, it is not sufficient for only experts to be knowledgeable about the type of multi-use concept discussed in this paper. To remain meaningful, the public has to be included in the knowledge production in order to understand processes that take place in our economies, environment and societies which in turn will affect the outcomes of our research.

The objective of this contribution is to explore the practical application of offshore aquaculture within offshore wind farms from the perspective of the different stakeholders involved. The consideration of combining different uses is driven by the notion to meet the quest of spatial scarcity in the marine realm [1]. Our premise is that a multi-use concept combining sustainable marine energy and food production would benefit from a better understanding of the rationalities and interests among the different stakeholder groups involved. The identification of potential benefits and constraints, and the formulation of key research gaps may help to guide policy makers and the research community towards tailored, problem-focussed solutions to meet the challenge of sustainable offshore aquaculture.

\section{Methodology}

The OOMU project is part of a successive series of multidisciplinary research projects that were initiated as early as 2001 with a focus on combining offshore wind energy and marine aquaculture $[31,32,1,3]$. The stakeholder workshop presented in this paper therefore builds on outcomes of previous workshops and interviews initiated in 2003 by the German shellfish growers in Emmelsbüll-Horsbüll [12] as well as by socio-economic scientists in 2005 in Bremerhaven [33]. While previous projects studied potentials for mussel and algae farming in offshore wind farms, the OOMU project focused additionally on fish aquaculture in an IMTA concept. ${ }^{1}$ Many of the stakeholders have been part of the ongoing research process since its very beginnings and still remain to date.

This paper primarily reflects on the outcomes of a stakeholder workshop that was conducted on September 7th, 2011 in Bremerhaven, Germany. The stakeholder workshop was part of a broader stakeholder analysis that was conducted within the OOMU-project to identify key stakeholders and their potential roles, attitudes, and concerns regarding an aquaculture/wind farm integration at the offshore location "Veja Mate". ${ }^{2}$ The stakeholder analysis was

\footnotetext{
${ }^{1}$ The aim of IMTA is the creation of a manageable small ecosystem with several species of different trophic levels combined in one system in the right proportions, each utilizing waste products or the biomass generated by another member of the system. While fish functions as the "fed" component producing waste, seaweed and shellfish act as the "extractive" part more or less in an ecosystem services manner.

${ }^{2}$ Veja Mate is the second wind farm to be realized under the planning authorization of BARD Engineering. In August 2009, Germany's Federal Maritime and Hydrographic Agency (BSH) granted planning approval for the new offshore wind farm that will border BARD Offshore 1 to the western side. In total, 80 wind turbines will be installed on an area of $50 \mathrm{~km}^{2}$. Veja Mate is the case study example within the OOMU project.
} 
based on internet and literature research, studies by partner institutions as well as 24 semi-structured interviews with selected stakeholders from fisheries and the offshore wind industry, environmental NGOs, public agencies and research. The selection was done by a prior extensive stakeholder survey, in which the central stakeholders of each affected sector were identified.

The workshop was limited to 42 participants to allow a fruitful discussion and avoid an impersonal mass event. The participants were representatives from fisheries and the fish processing industry, wind farm operators, governmental agencies, research institutes and professional associations. Scientists from multiple disciplines (including fisheries economics, marine biology, marine law and policy, coastal and water engineering, steel construction, aquaculture and sea ranching, socio-economics, sustainable resource management, and economics) accounted for half of the participants (50\%), which reflects the growing interest of the research community in the topic of the workshop. The workshop also attracted a considerable number of federal as well as regional governmental agencies in the fields of environmental protection, agriculture and fisheries, and economic development/promotion, which accounted for $22 \%$ of the participants. The fisheries and fish processing industry, and the offshore wind energy sector represented $10 \%$ and $7.5 \%$ of participants, respectively. Fig. 3 shows the distribution of stakeholders of workshops in 2005 and 2011.

The overall aims of the workshop were (1) to present and critically discuss the findings of the OOMU project, (2) to identify stakeholders' concerns and expectations with respect to marine aquaculture in offshore wind farms, and (3) to identify research gaps and opportunities of future collaboration to further our knowledge on multi-use approaches in the marine realm.

Participants were provided with a background document prior to the workshop to prepare for the discussions. The document contained a brief overview over the key research questions, goals of the workshop and background information to the OOMU project. The workshop itself was organized in several successive sessions. Opportunities for discussion were used widely throughout the different sessions of the workshop.

The first workshop session presented outcomes of the key research areas of the OOMU project: (1) biology including candidate species, their biology and culture conditions, (2) aquaculture economics, (3) technology and system design, as well as (4) ICZM including socio-economics and the legal framework. In the subsequent session, the participants, depending on their central interests and knowledge, were asked to split up into four thematic working groups (1-4). Each of these working groups was hosted by a rapporteur who was also an active research member in this topic within the OOMU project. All groups were asked to identify perceived potentials, constraints and research gaps of marine aquaculture in offshore wind farms in relation to the respective theme. In a final session, the outcomes of the group work were presented by the respective rapporteurs. These findings were jointly discussed among all participants. Missing knowledge areas were identified, and opportunities for future transdisciplinary cooperation were explored.

While this paper largely relies on the outcomes of the workshop, findings from the interviews are included as additional sources where appropriate. In particular, interviews with environmental NGOs, and the fisheries and offshore wind energy sectors were used to complement and verify workshop findings.

\section{Results}

Following a brief summary on the central aspects of the OOMU project findings, the central issues, statements and views that emerged in the group discussions are detailed. As some of the issues were raised in several of the parallel working groups, the

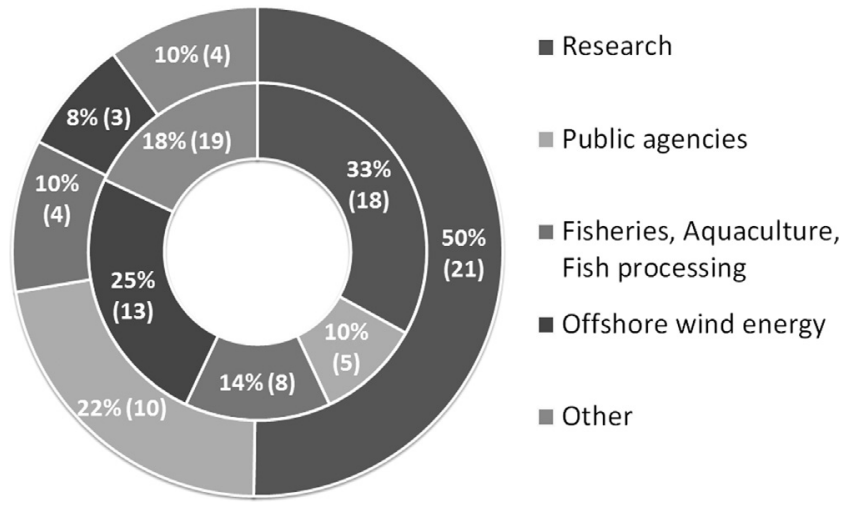

Fig. 3. Participants and their social affiliation of two stakeholder workshops held in Bremerhaven (Germany). The 1st workshop (inner circle) was conducted by the Alfred Wegener Institute Helmholtz Center for Polar and Marine Research (AW) in 2005 and the 2nd workshop (outer circle) was conducted by the Institute for Marine Resources (IMARE) in 2011. Numbers in brackets display the quantity of participants.

results are clustered into thematic issues and presented in a synthesized manner. The key issues are discussed in view of current literature, and gaps of knowledge and potential avenues of future research are formulated.

\subsection{Summary of OOMU project presentations}

The main results of the sub-project (1) "biology" was the identification of potential candidates to be cultivated at the offshore site Veja Mate with regard to an IMTA concept. Species identified were (a) fish: seabass (Dicentrarchus labrax), cod (Gadus morhua), halibut (Hippoglossus hippoglossus), turbot (Psetta maxima), salmon (Salmo salar), Atlantic wolffish (Anarhichas lupus), and Spotted wolffish (Anarhichas minor), (b) bivalves: European oyster (Ostrea edulis), Pacific oyster (Crassostrea gigas), Blue mussel (Mytilus edulis) and seaweed: sugar kelp (Sachccharina latissima), Oarweed (Laminaria digitata), dulse (Palmaria palmata). These are native species in the North Sea as the avoidance of the introduction of new species is of prime interest. The technical requirements to culture these species were defined and communicated to the other sub-project coordinators. The sub-group (2) "economics" used these results to calculate the commercial potential at the site Veja Mate while also including the data of the technical sub-group. Main results were the identification of a submergible cage design to grow turbot connected to the tripile foundation of the BARD wind turbine. The sub-group (3) "techniques" calculated various cage system designs within the tripile foundation and in the vicinity of a turbine calculating potential drag forces, and by using the data of groups (1) and (2) suggested a spherical cage design. The sub-group (4) "ICZM, acceptance and co-management" conducted a desk-top study on the regulatory environment for offshore mariculture and combined uses in Germany, as well as a stakeholder analysis, the results of which form the backbone of this paper.

\subsection{Summary of group discourse}

After a first round of intensive discussion, the workshop participants spread out into the four thematic working groups. The distribution among the thematic groups was fairly even in terms of numbers of attendees. The biology/ecology group was attended mostly by representatives from the public environmental sector and research, while the economic group attracted mainly fish (processing) and aquaculture industry representatives. Offshore wind and maritime technology industry gathered 
predominately in the technology group. The socio-economics and legal group consisted of researchers from a broad range of disciplines as well as public sector representatives.

Participants from all sectors actively engaged in the discussions which evoked as many supportive as critical commentaries. Table 1 summarizes the key perceived opportunities and constraints as compiled by the four thematic working groups. In the course of analysing the results from the individual workshop sessions, it became apparent that many of the topics were discussed in several of the working groups. The results were therefore synthesized to identify the central, the most critical, and controversial issues.

\subsection{Central stakeholder topics}

The stakeholder workshop and the previous semi-structured interviews revealed a generally high acceptance of an integration of marine aquaculture and offshore wind energy among most stakeholders in the German North Sea context. The spatial requirements for offshore wind energy are immense and priority areas for the sector were designated as part of the marine spatial planning process. Other uses of the area such as for fishing are entirely prohibited according to the German marine spatial planning regulation. However, as surfaced reappearingly in the discussions, it seemed reasonable to many of the stakeholders to allow other uses of the marine space such as marine aquaculture. Many of the stakeholders felt that the vast marine areas occupied by offshore wind energy could not legitimately be blocked by one user only but should be open to other users as well. However, what other uses that would entail remained a highly debated issue over the course of the workshop.

\subsubsection{Policy issues}

At a very early stage, in the first workshop session slot, the role of policy-makers was discussed controversially. The question was raised whether there was a political consensus to promote multiple ocean uses. While there seemed to be an agreement among the representatives of the research community that there was a strong political interest in investigating and supporting the integration and combination of a variety of ocean uses, representatives from public environmental agencies challenged that very perception. They pointed to the need to clearly define what is meant by "multiple ocean uses" and argued that marine space nowadays is already subject to a broad range of uses, so the question whether or not to promote multiple uses was misleading. In this context, the advantages of "no use" as opposed to "multiple uses" were also discussed. Environmental agency representatives pointed to the beneficial environmental effects of closed wind farms such as reduced pressure on fish stocks, recuperation of the benthic environment and were fearful that any additional use would jeopardize such effects. This discussion pointed to a general conflict as to which extent marine space should be subject to human uses.

\subsubsection{Environmental issues}

A major concern of participants from across the range of stakeholder groups was how to avoid negative impacts of aquaculture

Table 1

Work group results: potentials and constraints of marine aquaculture - offshore wind energy co-use as perceived by stakeholders.

\begin{tabular}{|c|c|c|}
\hline & Potentials & Constraints \\
\hline $\begin{array}{l}\frac{\text { Theme } 1}{\text { Biology and }} \\
\text { ecology }\end{array}$ & $\begin{array}{l}\text { - Favourable hydrographic conditions (water quality, strong water } \\
\text { exchange) } \\
\text { - Lesser environmental impacts than nearshore aquaculture } \\
\text { - Seasonal models with alternating species depending } \\
\text { on seasonal or life-cycle requirements and environmental } \\
\text { conditions (e.g. warm water species in summer and cold water } \\
\text { species in winter; or cultivation only in summer) }\end{array}$ & $\begin{array}{l}\text { - Harsh environmental conditions: high temperature variation, strong } \\
\text { currents - habitable for only very limited number of species, low } \\
\text { growth rate, higher risk of infection } \\
\text { - Interactions between caged fish and wild fish } \\
\text { - Potential impacts on marine environment (nutrient input, noise } \\
\text { impacts) } \\
\text { - Fouling }\end{array}$ \\
\hline $\begin{array}{l}\text { Theme } 2 \\
\text { Socio-economics } \\
\text { \& legal } \\
\text { frameworks }\end{array}$ & $\begin{array}{l}\text { - Additional income for the region } \\
\text { - Well developed legal framework for offshore wind energy } \\
\text { facilities - need to adapt/extend framework to marine } \\
\text { aquaculture requirements } \\
\text { - Additional "selling point" for offshore wind operators when } \\
\text { applying for permit } \rightarrow \text { improving acceptance of the public and } \\
\text { the permit granting agency }\end{array}$ & $\begin{array}{l}\text { - Conflicting views on favourable uses or non-uses } \\
\text { - High investment cost, therefore not attractive for individual fishermen; } \\
\text { possibly only marginal income effects } \\
\text { - Very limited know-how of aquaculture farming in Germany } \\
\text { - Legal uncertainties with respect to e.g. property rights in the EEZ, legal } \\
\text { definitions versus customary use of terms such as "offshore", "harmful } \\
\text { effects", applicability of laws and regulations in the EEZ } \\
\text { - Uncertainty with respect to liability and insurance issues and legal } \\
\text { tenure arrangements }\end{array}$ \\
\hline $\begin{array}{l}\text { Theme } 3 \text { Economic } \\
\text { viability \& } \\
\text { operation }\end{array}$ & $\begin{array}{l}\text { - Cost reduction potential by co-use of infrastructure (shared } \\
\text { maintenance costs) } \\
\text { - Target premium segment, high-quality, organic production } \\
\text { - Identify selling points (e.g. high quality, organic certification, } \\
\text { local production) } \\
\text { - Develop technological leadership, pioneering spirit - open up } \\
\text { export markets } \\
\text { - Mussel and seaweed cultivation more promising in terms of } \\
\text { economic return than fish cultivation } \\
\text { - Bio-engineering, bio-extraction of mussel and macro algae } \\
\text { products and by-products }\end{array}$ & $\begin{array}{l}\text { - High risk/uncertainty with respect to price developments } \\
\text { - High costs of investment } \\
\text { - Range of species very limited due to biological requirements }\end{array}$ \\
\hline$\frac{\text { Theme } 4 \text { Technology }}{\text { \& design }}$ & $\begin{array}{l}\text { - Reduced costs for maintenance and cleaning works (sharing of } \\
\text { fixed costs e.g. for vessels) } \\
\text { - Tension leg systems for detached systems } \\
\text { - Development of novel technical solutions for potential export }\end{array}$ & $\begin{array}{l}\text { - Higher cost in development \& application process } \\
\text { - Safety concerns for workers } \\
\text { - Smoothness of operations of wind energy facility possibly impaired } \\
\text { - Uncertainty with respect to stability/robustness of tripile when cage is } \\
\text { attached (do tripiles have to be reinforced to withstand tractive forces } \\
\text { of aquaculture cage? At what addition costs?) }\end{array}$ \\
\hline
\end{tabular}


operations on the marine environment. Potential ecological and biological impacts and related uncertainties were raised throughout the general discussion as well as the more specific working group discussions. Public environmental agencies are concerned in particular about the impacts of nutrients on the benthic environment and pelagic fauna and pointed to the negative experiences with aquaculture elsewhere. The idea of combining fish farming and mussel production in a polyculture / IMTA approach provoked a very controversial discussion among some scientists and public agency representatives. As one public environmental agency representative provocatively put it: "If the nutrient input is as minimal as you want to make us believe-what would the mussels feed on?" It became apparent that there were quite different understandings of "favourable hydrological conditions": while to some the North Sea conditions were relatively favourable (e.g. shorter water retention times than in fjords), others considered the North Sea as relatively susceptible to eutrophication. The need for locale-specific nutrient budgeting and carrying capacity analyses was clearly articulated in this discussion. Also biological concerns such as noise impacts on fish and interactions between caged and wild fish were discussed in this context. According to the biologists involved in the OOMU project, the harsh offshore conditions (high temperature variation, strong currents, high tides) indeed pose a limiting factor in the selection of cultured species. A desk-top study within the OOMU project identified seven fish species (D. labrax, G. morhua, H. hippoglossus, P. maxima, S. salar, A. lupus and A. minor) as potentially appropriate. However, being a first assessment study, these results remain highly hypothetical. Further research is needed to test the suitability of the selected species under real conditions in offshore environments. Many of the session participants were doubtful whether the biological requirements of fish could be met under such extreme conditions.

\subsubsection{Economic issues}

The potential economic viability was heavily debated during the workshop, and the results of the economic studies of the OOMU project underpin the many uncertainties in this respect. As economic and biological studies focused on the selected species mentioned above, group discussions focused on potentials for those species. Representatives of the fish industry were clearly supportive of marine aquaculture in offshore wind farms. Given the high investment and operation and maintenance costs of an offshore marine aquaculture installation, industry representatives suggested targeting the high price market segment (niche) and concentrate on high quality products such as sole, turbot or wolffish and certified organic production. In order to market such high quality products, the importance of identifying unique selling points was emphasized by participants of the economics and industry working group. Since the demand for locally produced, organic products is, as elsewhere, on the rise in Germany, certified organic fish from local production off the coast was considered a strong selling point. Investing in the development of suitable offshore technologies was also considered an opportunity to develop technological leadership in this field and possibly open up an avenue for novel export markets in other countries such as China where aquaculture production plays a much larger role than in Germany.

\subsubsection{Socio-economic issues}

The discussion above points to some key underlying questions: What is the target market of the technologies? Who would run an offshore mariculture installation, in what way (e.g. taxation, promotion of corporate social responsibility (CSR), etc.) and who would gain the economic returns? These questions were also addressed in the socio-economics and legal frameworks group. Some of the stakeholders raised their concerns that a large, possibly foreign investor would operate the farm without generating any or only marginal benefits for the coastal region and local workforce. There was a consensus within the group, and interviews with fisheries associations seem to support this view, that local fishermen are rather unlikely to engage in marine farming. Neither are they sufficiently qualified, nor do they possess sufficient investment capital, nor do they seem to be willing to move away from their original profession. The latter points to the selfperception of this stakeholder group and thus stresses the importance of transdisciplinary research approaches. Along with the technical and operational design of the facility, it is therefore equally important to identify the potential target group for the operations and define specific job requirements (know-how, equipment).

\subsubsection{Legal issues}

Additionally, the socio-economics and legal frameworks group identified a number of legal uncertainties relating to marine aquaculture in offshore waters and combined uses. While the regulatory and policy framework for offshore wind farms in Germany is generally perceived as comprehensive, wellstructured and predictable, the legal framework for marine aquaculture, let alone for combined uses, is weak and fragmented. The workshop discussion confirmed findings from previous interviews and literature research (see for example [34,1]), that the applicability of laws and regulations - such as the Marine Facilities Ordinance or the Federal Fisheries Law - to marine aquaculture in offshore waters is far from clear. A lack of legal definitions on basic parameters such as "offshore" or "hazardous marine environmental impacts" further hampers an estimation of which laws and regulations would apply under which conditions. Since marine aquaculture in offshore waters is a hypothetical scenario (at least currently in Germany), there are no precedent cases to which one can refer to. In particular the uncertainty on property rights is an obstacle for potential investors. The current legal framework in Germany does not include provisions for licensing agreements in offshore waters. What legal standing a mariculture operator could secure, whether and how he could obtain a licence from the permit holder (i.e. wind farm operator), remains highly hypothetical.

\subsection{Key research gaps}

From the presented results of the stakeholder workshop, additional stakeholder interviews, as well as literature research, a number of key research gaps were identified which are presented in Table 2.

\section{Discussion}

Engaging with other fields of research and a wide range of different stakeholder groups with often diverging and vested interests can be a time-consuming process. It is hampered by the difficulty of fully endorsing the rationality behind the participating stakeholders and their views that are different to our own, since the way that individuals understand systems is also a reflection of how each individual has been exposed to the subject of concern (e.g. the role of mental mind-models in ecosystem management, see [35-37]).

As in all participatory arenas, the crucial question remains "who participates?" The selection of participants can be viewed as a constitutional decision for the legitimacy, the course and the topics of each participatory procedure and its outcomes. Furthermore, the steps and approaches involved in this process bear high relevance for the success of the procedure, e.g. informative methods versus co-ordination of different forms and fields of 
Table 2

Summary of work group discourse on perceived central research gaps of of marine aquaculture-offshore wind energy co-use.

\begin{tabular}{|c|c|}
\hline & Key research gaps \\
\hline Theme 1 Biology \& ecology & $\begin{array}{l}\text { - Locale-specific nutrient budgeting (lab+field research), carrying capacity analyses, prediction of impacts on surrounding } \\
\text { marine environment (benthic environment, pelagic fauna) } \\
\text { - Further research on biological requirements and suitability of selected species under offshore conditions (field research) } \\
\text { - Novel feeding techniques with optimal feed use need to be developed } \\
\text { - Potential role of IMTA systems }\end{array}$ \\
\hline $\begin{array}{l}\text { Theme } 2 \text { Socio-economics \& legal } \\
\text { frameworks }\end{array}$ & $\begin{array}{l}\text { - Identification of site selection criteria (including environmental, economic, socioeconomic, and technological parameters) and } \\
\text { - standards for approval procedure to support/guide public agencies when dealing with project proposals } \\
\text { - Identification of target group and their specific requirements for the operation of a marine aquaculture installation } \\
\text { - Further research into possible legal arrangements } \\
\text { - Development of stringent and binding mode of project development with reference criteria } \\
\text { - Identification of uncertainty factors for business developers }\end{array}$ \\
\hline $\begin{array}{l}\text { Theme } 3 \text { Economic viability \& } \\
\text { operation }\end{array}$ & $\begin{array}{l}\text { - More reliable, detailed calculations of predicted costs, economic return, break-even point possible when cage design and species } \\
\text { selection completed } \\
\text { - standards for approval procedure (likewise "STUK" for offshore wind farms) need to be developed so to assess additional costs } \\
\text { and efforts of offshore aquaculture }\end{array}$ \\
\hline Theme 4 Technology \& design & $\begin{array}{l}\text { - construction of a showcase cage operating under real offshore conditions to assess feasibility and practicability of } \\
\text { technical design } \\
\text { - Connecting / coupling strategies } \\
\text { - Automated feeding technologies } \\
\text { - antifouling - need for technological advancements for removal of fouling, anticorrosion systems } \\
\text { - Development of alternative technical solutions for cages that are not attached to turbine }\end{array}$ \\
\hline
\end{tabular}

knowledge [29]. Such considerations are extremely important, as reflected by the discussions at the OOMU workshop. Here, highly controversial attitudes, perceptions, concerns and interests across the range of stakeholders were revealed. Indeed, neither at the more general level (e.g. do stakeholders support the idea of cousing marine waters in offshore wind farms?), nor at the more specific level (e.g. how can such a co-use be brought about?) was a consensus achieved. In the following, some of the central topics as identified during the workshop are discussed in more detail.

\subsection{Policy issues}

At policy-level, the workshop discussions as well as the interviews revealed the ambiguities of a very heterogeneous group of stakeholders. While the overall trend towards increasing, variable uses of offshore waters was undisputed, public agencies at federal and state level were at odds with how to deal with, benefit from, or even counteract this development. At EU level, recent developments in marine and coastal policy indeed follow the paradigm of integrating and accommodating for multiple sustainable uses of ocean space. While the EEZ until recently was a fairly unregulated space, a number of binding as well as non-binding regulations and policies have been implemented to regulate the uses of the EEZ. For instance, at EU level, the Integrated Maritime Policy, the Marine Strategy Framework Directive and the Common Fisheries Policy triggered far-ranging changes in legal and policy frameworks in Germany. Amendments such as the Federal Law on Water, the Federal Environmental Protection Act, the Federal Fisheries Law, the Marine Facilities Ordinance, and the Federal Spatial Planning Law are results of this process. Indeed, the current push for offshore wind energy in Germany further necessitated and accelerated the process of providing a legal framework for ocean use. As one of the first European countries, Germany has produced comprehensive and legally binding Marine Spatial Plans for its offshore territory [38,39]. The Marine Facilities Ordinance and its successive planning permission procedure were explicitly designed for marine offshore area utilization, establishing a clearly structured approval procedure for offshore installations. Within this process of a changing regulatory environment, policy-makers in Germany are challenged with adapting their policies and delimiting their room for manoeuvre within the new framework. How laws and regulations apply to marine aquaculture in offshore wind farms is as yet uncertain and subject to interpretation. The workshop discussions and interviews with governmental agencies revealed divergent and to some extent conflicting views on how to apply and interpret current laws and regulations. Such major reforms pose immense challenges to the implementing agencies as they fundamentally alter legislative and administrative procedures, and roles and responsibilities of actors involved. At the same time, recent developments at EU as well as national policy level provide a window of opportunity for policy makers, researchers and entrepreneurs alike to showcase examples of sustainable, combined uses of the ocean space.

Within this commingling of interests, interpretations, and policy approaches, it is crucial to understand and acknowledge the different views and concerns within different layers of public administration. Undoubtedly the marine research community receives significant public funding to study sustainable uses of the sea. This is mirrored by the initiation of three major projects, namely MERMAID, TROPOS and H2OCEAN under the umbrella of the $2011 \mathrm{EU}$ "Ocean of Tomorrow" Call. ${ }^{3}$ These developments show a clear commitment of policy makers in Germany and within the European Union to further investigate sustainable, multiple uses of the offshore sea.

\footnotetext{
3 The project MERMAID aims to develop theoretic concepts for the next generation of offshore platforms which can be used for multiple purposes including energy extraction, aquaculture and platform related transport (see http://www.mermaidproject.eu). TROPOS is a European collaborative project which aims at developing a floating modular multi-use platform system for use in deep waters (see http://www.troposplatform.eu). H2OCEAN is the third project of this EU Call. It aims at developing an innovative design for an economically and environmentally sustainable multi-use open-sea platform. Hereby, wind and wave power will be harvested and part of the energy will be used for multiple applications on-site, including the conversion of energy into hydrogen that can be stored and shipped to shore as green energy carrier and a multi-trophic aquaculture farm (see http://www.h2ocean-project.eu).
} 


\subsection{Environmental issues}

At the same time, the workshop and the interviews revealed very outspoken criticism and scepticism from the environmental departments within public administration. One of the key concerns of many of the representatives from federal and state environmental agencies - and also of environmental NGOs and parts of the research community - related to harmful impacts of fish farming on the marine environment. If not managed properly, aquaculture is an economic activity with potentially adverse impacts on the environment, and stakeholders in Germany as in other countries are alert to potentially polluting activities in coastal and marine areas. Potentially adverse impacts of aquaculture in general are well known and described in literature (e.g. [40]), and best practice examples from all over the world demonstrate a growing body of knowledge and experience to find technological solutions to address those impacts (e.g. [41]). Being a relatively new technology, experience with offshore aquaculture is limited at present. Recent research in the U.S. has specifically looked at potential environmental impacts of marine (offshore) aquaculture [42] and governance frameworks to support environmentally sustainable marine aquaculture [43-45]. Virtually no experience exists demonstrating the potential impacts of multiple offshore wind energy - aquaculture installations. The workshop and the supporting interviews revealed a very distinct need to address environmental concerns early in the technology development process. Locale-specific nutrient budgeting, carrying capacity analyses, and the identification of site selection criteria (taking into account environmental as well as economic, socio-economic, and technological parameters) were identified as research priorities for future research.

\subsection{Operational issues}

The effects on the marine environment naturally depend on the way the enterprise is managed and set up. At operational level, the workshop discussions and interviews pointed to a number of unresolved issues and areas of possible conflict. The studies of the OOMU project were based on the assumption of a comanagement between two users of a shared ocean area: the wind farm operator and the operator of an aquaculture farm. Wind farm operators however are highly concerned about safety and smoothness of operations when sharing the same area, and possibly some of the equipment, with a co-user. [33,46,2,47] have identified a number of possible mutual benefits from a marine aquaculture offshore wind energy co-use, such as task allocation, resource exchange, linkage of different types and levels of organization, reduced transaction costs, risk sharing and conflict resolution. However, as long as technological and operational needs for an aquaculture installation are uncertain, potential benefits remain vague while safety risks appear more tangible and measurable. The sector is still in its very early stages of development and is currently facing enormous difficulties and uncertainties. The current shift of the planning procedures in 2012 in the German marine realm towards a plan-approval procedure for offshore projects are a case in point. Our interviews indicated that the sector felt it was too early to consider attaching anything to the basis of the installation thus adding even more uncertainties to the process. As the legal situation at the moment gives the wind sector the privilege of a single user right, the sector is, given the high investment costs involved, reluctant to considering additional uses of the same ocean space. The results from the workshop and the interviews indicate however, that the sector is highly aware of the importance of public opinion. As wind energy is a high priority on the national political agenda and receives massive financial and operational support, the prospects for the sector are clearly affected by public opinion and political will. If co-uses in offshore wind farms become widely accepted and politically "wanted" - as quite a few of the workshop and interview participants believe -, marine aquaculture might turn out to be an additional selling point for wind farm operators. In the view of the wind farm planners and operators, a co-use of the offshore site in-between the wind farms without a connection to the turbine is clearly more favourable. Further research is needed to study a variety of alternative technical solutions, taking a closer look at solutions that are not attached to the turbine.

\subsection{Socio-economic issues}

While the interests and concerns of the offshore wind industry are fairly well understood and have been studied in other contexts as well (e.g. [48]), the role of the potential co-user continues to remain vague and hypothetical, mainly because it is not clear who would actually operate an offshore aquaculture installation. Aquaculture is not a dominant industry in Germany, and lack of human capital might be a key obstacle for operation. Interviews with representatives from fisheries associations revealed a low acceptance of marine aquaculture in general; this was also documented by studies undertaken by [49]. The romantic view that fishermen bereft of fishing grounds might turn to marine farming seems to be a misperception of reality. Quite the contrary: at this point in time, proposed alternative uses in offshore wind farms - including aquaculture - seem to be perceived by some fisheries representatives as lip service to appease those that lost their fishing grounds. The low representation of the fisheries sector at the workshop also points to the very limited interest in proposed uses such as marine aquaculture. Moreover, due to the remoteness of an offshore installation, the construction would have to rely heavily on automated processes; local employment and income effects might thus only be marginal. However, this reinforces the crucial role of early and continuous stakeholder engagements to reveal hidden misperceptions of potential roles that stakeholders may play in this context.

One of the key questions that emerged during our stakeholder analysis was whether marine aquaculture in offshore wind farms was a win-win scenario benefiting all involved parties, or whether there were any "losers" in the process. Since the combination of marine aquaculture and offshore wind energy is a novel and as yet untested idea in the North Sea context, assumptions of who would benefit from, and who would lose under such a scenario are hypothetical. The results from the stakeholder workshop, interviews as well as the insights gained by the long-lasting experience of continuous stakeholder engagement since 2001 on this subject may only indicate in what way stakeholders feel - or fear - they might be affected. Such personal views are momentary and dynamic and may be influenced by further research outcomes. The authors therefore refrain from dividing the stakeholders into "supporters" and "opponents" but rather consider the findings as a snap shot of stakeholders' attitudes and perceptions based on the current state of information.

A clear message from the workshop - as well as from the stakeholder interviews - is that there are stakeholders on both the "winning" and the "losing" side. Interestingly, the majority of participants (and interviewees) supported in principle the multiple use approach as a pragmatic solution to ever increasing demands for ocean space. While the intensification of ocean use in itself is a cause of concern to many of the stakeholders, the need for finding sustainable ways of integrating new developments such as marine aquaculture and wind farming was fairly undisputed. But it also became apparent that certain groups of stakeholders are felt left out (or "overrun") in this run for ocean space. There also needs to be a clear distinction between short term benefits versus long-term losses. Only if the interests of the involved parties are truly understood, and the short as well as 
long term impacts are clearly linked to the multiple stakeholders engaged in the process, can the cumulated, variable effects to society and the environment be fully appreciated.

\section{Conclusions}

Balancing the needs and interests of multiple stakeholders lies at the heart of policy-making; this holds especially true in areas where spatial claims clash with increasingly scarce resources and space, such as in coastal zones and increasingly also marine space. This makes the issue of how to tackle a multi-use approach for the offshore area so difficult, even more so, if one addresses sustainability and equity issues in its wake. Our research results confirm the assumption that there is a clear need, and also willingness on behalf of the policy makers and the research community, to find sustainable, resource- and space-efficient solutions for combined ocean use. The OOMU concept holds the potential to showcase a successful solution of a twofold-use of the same ocean territory.

In capturing different stakeholder knowledge forms in a transdisciplinary approach, it however became apparent that the orchestration of a multi-use concept for the offshore realm is extremely difficult. A multitude of potential benefits as well as risks and uncertainties were articulated and discussed in the process.

Some of the stakeholder concerns related to very specific open questions, such as economic viability, nutrient impacts, technological and operational risks, that may easily be resolved as research and technology development progresses; hence results and predictions become more reliable. Further research in particular in the proposed focus areas can play a key role to allow for more reliable predictions of technical, biological and economic feasibility, which are indispensable for offshore wind farm operators and mariculturists to support and actively engage in any further developments in this field.

Other criticisms on the other hand were of a more principal nature. To some stakeholders the mere exploration of new uses imposes a threat; to them that favour a no-use of wind farm areas or fear to lose their own user rights it is not sufficient to prove (technological, economic, biological) feasibility of such a co-use. Appreciating their interests and finding solutions to their concerns is challenging yet critical for the success of a concerted offshore multi-use activity. This demands an insight into the existing underlying ideas, interests and normative considerations of the various stakeholder groups to understand the complexity of perceived problems and to overcome misunderstandings.

Engaging in stakeholder dialogues via workshops can provide a concept for linking scientific insights with local knowledge or stakeholders' insights towards participatory knowledge creation. Therefore, the generation and effective transmission of knowledge within different stakeholder groups is an overriding concern for the future. In this respect, our approach based on including a wide range of different stakeholders of different topical spheres and institutional levels in one workshop session can be viewed as a first stepping stone to truly engaging into a dynamic two-way interplay where learning takes place and future actions can emerge.

\section{Acknowledgement}

The authors would like to thank all stakeholders involved in the long-standing, fruitful discourse on marine aquaculture-offshore wind energy co-use. This work was carried out as part of the project "Multiple Nutzung und Co-Management von OffshoreStrukturen: Marine Aquakultur und Offshore-Windparks (Open Ocean Multi-Use (OOMU))" and financed by the Federal Ministry for the Environment, Nature Conservation, Building and Nuclear Safety, Project no: 0325206.

\section{References}

[1] Buck BH, Krause G, Rosenthal H. Extensive open ocean aquaculture development within wind farms in Germany: the prospect of offshore comanagement and legal constraints. Ocean Coast Manag 2004;47(3-4):95-122.

[2] Buck BH, Krause G, Michler-Cieluch T, Brenner M, Buchholz C, Busch JA, et al. Meeting the quest for spatial efficiency: progress and prospects of extensive aquaculture within offshore wind farms. Helgol Mar Res 2008;62:269-81.

[3] Buck BH, Krause G. Integration of aquaculture and renewable energy systems. In: Meyers RA, editor. Encyclopedia of sustainability science and technology. New York: Springer; 2012.

[4] Kamermans P, Schellekens T, Beukers R. Verkenning van mogelijkheden voormosselteelt op Nordzee. IMARES Wageningen UR; 2011 (Rapport C021/ 11).

[5] Vanagt T, Van de Moortel L, Calewaert JB. Offshore wind and aquaculture in the Belgian North Sea: opportunities and pitfalls. 2012 (eCOAST report 2011005).

[6] Syvret M, FitzGerald A, Wilson J, Ashley M, Ellis Jones C. Aquaculture in Welsh Offshore Wind Farms: A feasibility study into potential cultivation in offshore wind farm sites. Report for the Shellfish Association of Great Britain. 2013.

[7] Lacroix D, Pioch S. The multi-use in wind farm projects: more conflicts or a win-win opportunity? Aquat Living Resour 2011;24:129-35.

[8] Polk M. Open ocean aquaculture. In: Proceeding of an international conference. Portland-ME (USA): New Hampshire/Maine Sea Grant College Program Rpt.\# UNHMP-CP-SG-96-9; May 8-10, 1996.

[9] Biran AB. Proceedings of the Workshop on Offshore Technologies for Aquaculture. Haifa, Israel: Technion, Faculty of Mechanical Engineering; 1999.

[10] Costa-Pierce B.A. The ecology of marine wind farms: perspectives on impact mitigation, siting, and future uses. In: Proceedings of the 8th Annual Ronald C. Baird Sea Grant Science Symposium. Newport, Rhode Island, USA; November 2-4, 2009.

[11] Emmelkamp L. Workshop on prospects for mariculture in the Dutch North Sea. Dutch Fish Product Board. Amsterdam, The Netherlands. MARE - Centre for Maritime Research; March 26th 2003.

[12] Ewaldsen P. Protocol of the 1st session of the expert meeting dealing with fisheries, offshore wind farms and open ocean aquaculture. Germany: Emmelsbüll-Horsbüll; 2003 (10 p.).

[13] Helsley CE. Open Ocean Aquaculture'97, Charting the Future of Ocean Farming. In: Proceedings of an international conference. University of Hawaii Sea Grant College, Maui-HI, USA; April 23-25. 1997.

[14] Michler T. Workshop "Marikultur in Offshore-Wind parks", BMBF Projekt Coastal Futures-ZukunftKüste. Alfred Wegener Institute for Polar and Marine Research, Bremerhaven [accessed 18.11.04]

[15] Rosenthal H, Costa-Pierce BA, Krause G, Buck BH. Bremerhaven Declaration on the Future of Global Open Ocean Aquaculture-Part II: recommendations on subject areas and justifications. Aquaculture forum on open ocean aquaculture development - from visions to reality: the future of offshore farming. Funded by: investment in sustainable fisheries co-financed by the European Union (European Fisheries Fund-EFF), Ministry of Economics, Labour and Ports (Free Hanseatic City of Bremen), The Bremerhaven Economic Development Company Ltd.; 2012. 8 p.

[16] Ryan J. Farming the Deep Blue. Report of an offshore aquaculture conference, Limmerik, Ireland; 6-7 October 2004.

[17] Stickney RR. Joining forces with industry. In: Proceedings of the third international conference on open ocean aquaculture. Corpus Christi-TX (USA). TAMU-SG-99-103; May 10-15 1998.

[18] Bridger CJ, Costa-Pierce BA. Open ocean aquaculture: from research to commercial reality. Baton Rouge, Louisiana, USA: The World Aquaculture Society; 2003.

[19] Mee L, Kavalam JP. Suitability of Offshore Wind Farms as Aquaculture Sites The Marine Institute, University of Plymouth Stakeholder Meeting, 1st March 2006. The Royal Institution of Naval Architects, London, UK; 2006.

[20] Muir J. Basurco B. Mediterranean offshore mariculture. Zaragoza: CIHEAM (Centre International de Hautes Etudes AgronomiquesMediterraneennes; 2000 (Serie B: Etudes etRecherches, No. 30 Options Mediterraneennes, 215 p.).

[21] vanBeek R, Florentinus A, Coulomb L, Sluijs Q Scheijgrond P. Marine Parks: Designs for sustainable energy and biomass at sea. Innovation network report no 08.2.168, Utrecht; June 2008.

[22] ICES. Report of the Working Group on Marine Shellfish Culture (WGMASC) Sopot, Poland: ICES CM 2012/SSGHIE:15; 20-23 March 2012. 117 pp.

[23] Hundt M, Goseberg N, Wever L, Ebeling M, Schlurmann T, Dubois J, et al Multiple Nutzung und Co-Management von Offshore Strukturen: Marine Aquakultur und Offshore Windparks, Tagungsband, 8. FZK-Kolloquium.Maritimer Wasserbau und Küsteningenieurwesen. Forschungszentrum Küste (FZK), Gemeinsame Einrichtung der Leibniz Universität Hannover und der technischen Universität Braunschweig; 2011.

[24] Buck BH, Dubois J, Ebeling MW, Franz B, Goseberg N, Hundt M, et al. Multiple Nutzung und Co-Management von Offshore-Strukturen: Marine Aquakultur und Offshore-Windparks. Open Ocean Multi-Use (OOMU)-Projektbericht, gefördert durch das Bundesministerium für Umwelt, Naturschutz und Reaktorsicherheit; 2012. 256p. 
[25] Klein JT. Evaluation of interdisciplinary and transdisciplinary research: a literature review. Am J Rev Med 2008;35(2S):116-23.

[26] Krause G, Welp M. Systems Thinking and Social Learning for Sustainability. In: Glaser M, Krause G, Ratter B, Welp M, editors. Human-nature interactions in the anthropocene: potentials of social-ecological systems analysis. New York, London: Routledge; 2012.

[27] Wenger E. Communities of practice and social learning systems. Organization 2002;7:225-46.

[28] Tàbara JD, Pahl-Wostl C. Sustainability learning in natural resource use and management. Ecol Soc 2007;12(2):3.

[29] Siebenhüner B. Social learning and sustainability science: which role can stakeholder participation play? Int J Sustain Dev 2004;7(2):146-63.

[30] Kates RW, Clark WC, Corell R, Hall JM, Jaeger CC, Lowe I, et al. Sustainability Science. Science 2001;292(5517):641-2.

[31] Buck BH. Open OceanAquaculture und Offshore-Windparks: Eine Machbarkeitsstudie über die multifunktionale Nutzung von Offshore-Windparks und Offshore-Marikultur im Raum Nordsee. Reports on Polar and Marine Research. Bremerhaven: Alfred Wegener Institute for Polar and Marine Research; 2002.

[32] Buck BH. Farming in a high energy environment: potentials and constraints of sustainable offshore aquaculture in the German Bight (North Sea). (Dissertation). University of Bremen, Germany; 2004.

[33] Michler-Cieluch T, Krause G. Perceived concerns and possible management strategies for governing 'wind farm-mariculture integration'. Mar Policy 2008;32(6):1013-22.

[34] Buck BH, Krause G, Rosenthal H, Smetacek V. Aquaculture and environmental regulations: The German Situation within the North Sea. In: Kirchner A, editor International Marine Environmental Law: Institutions, Implementation and Innovation. International Environmental Law and Policies Series of Kluwer Law International, vol. 64. The Hague: Kluwer; 2003.

[35] Glaser M. The social dimension in ecosystem management: strengths and weaknesses of human-nature mind maps. Hum Ecol Rev 2006;13(2):122-42.

[36] Glaser M, Glaeser B. The social dimension in the management of socialecological change. In: Kremer H, Pinckney J, editors. Treatise on estuarine and coastal science: integrated management of estuaries and coasts. München: Elsevier; 2012. p. 59.

[37] Glaeser B, Bruckmeier K, Glaser M, Krause G. Social-ecological systems analysis in coastal and marine areas: a path toward integration of interdisciplinary knowledge. In: Lopes P, Begossi A, editors. Current Trends in Human Ecology. Cambridge, UK: Cambridge Scholars Publishing; 2009. p. 20.

[38] von Daniels G, Uibeleisen M. Offshore-Windkraft und Naturschutz: Anforderungen an Offshore-Windparks in der deutschen AWZ. Z. neues Energierecht 2011;6:602-8.
[39] BSH. Spatial plan for the German Exclusive Zone in the North Sea. BSH; 2013.

[40] Pillay T. Aquaculture and the environment. Oxford, UK: Blackwell Publishing Ltd.; 2004.

[41] Tucker CS, Hargreaves JA. Environmental best management practices for aquaculture. Blackwell Publishing; 2008.

[42] Report of the Marine Aquaculture Task Force. Sustainable marine aquaculture: fulfilling the promise; managing the risks; 2007.

[43] Cicin-Sain B, Bunsick SM, DeVoe R, Eichenberg T, Ewart J, Halvorson H, et al. Development of a policy framework for offshore marine aquaculture in the 3200 mile U.S. Ocean Zone. Center for the Study of Marine Policy, University of Delaware; 2001.

[44] Cicin-Sain B, Bunsick SM, Corbin J, DeVoe MR, Eichenberg T, Ewart J, et al. Recommendations for an operational framework for offshore aquaculture in U.S. Federal Waters. Center for the Study of Marine Policy, University of Delaware; 2005.

[45] GAO. Offshore marine aquaculture: multiple administrative and environmental issues need to be addressed in establishing a U.S. Regulatory Framework. Report to the Chairman, Committee on Natural Resources, House of Representatives. United States Government Accountability Office; 2008.

[46] Michler-Cieluch T, Krause G, Buck B. Reflections on integrating operation and maintenance activities of offshore wind farms and mariculture. Ocean Coast Manage 2009;52:57-68.

[47] Krause G, Griffin RM, Buck BH. Perceived concerns and advocated organisational structures of ownership supporting offshore wind farm mariculture integration. In: Krause G, editor. From turbine to wind farms: technical requirements and spin off products. Rijeka, Croatia: InTech, Open Access Publisher; 2011.

[48] Bruns A, Gee K. From state-centered decision-making to participatory governance - planning for offshore wind farms and the implementation process of the water framework directive in Northern Germany. GAIA 2009;18(2):150-7.

[49] Michler-Cieluch T. Co-Management processes in integrated coastal management: the case of integrating marine aquaculture in offshore wind farms. (Dissertation). Universität Hamburg; 2009 (67p.).

\section{Web references}

〈http://www.mermaidproject.eu〉〈http://www.mermaidproject.eu〉. $\langle$ http://www.troposplatform.eu〉〈http://www.troposplatform.eu $\rangle$. 〈http://www.h2ocean-project.eu〉〈http://www.h2ocean-project.eu〉. 